\title{
Evaluation of Some Heavy Metals in Imported Chocolate and Candies Sold in Nigeria
}

\author{
J. O. Ochu ${ }^{1}$, A. Uzairu ${ }^{1}$, J. A. Kagbu ${ }^{1}$, C. E. Gimba ${ }^{1} \&$ O. J. Okunola ${ }^{2}$ \\ ${ }^{1}$ Department of Chemistry, Ahmadu Bello University, Zaria, Nigeria \\ ${ }^{2}$ National Research Institute for Chemical Technology, Zaria, Nigeria \\ Correspondence: O. J. Okunola, National Research Institute for Chemical Technology, P. M. B. 1052, Zaria, \\ Nigeria. E-mail: okunolaoj@gmail.com
}

Received: November 11, 2011 Accepted: November 25, 2011 Online Published: July 2, 2012

doi:10.5539/jfr.v1n3p169

URL: http://dx.doi.org/10.5539/jfr.v1n3p169

\begin{abstract}
This study was initiated as a follow-up information on some impounded products chocolates and candies (Samples A, B, C and D) imported from overseas, and sold in Nigeria markets. This result as their failure to meets Nation Agency for food drug administration and control (NAFDAC) regulatory standard. Samples of these products were collected in five markets of each six states each from the six geographical zones: North-West (Bauchi), North-East (Kano), North-Central (Kogi), South-West (Lagos), South-East (Abia), and South-South (Rivers) of the country. In order to evaluate the quality of the products, the levels of some heavy metals $(\mathrm{Cu}, \mathrm{Mn}$, $\mathrm{Fe}, \mathrm{Ni}, \mathrm{Zn}$, Ti and $\mathrm{Cr}$ ) were evaluated in the samples using X-ray fluorescence (XRF). Concentrations of metals in both chocolates and candies ranged $3.0-4.2 \mathrm{mg} / \mathrm{g}$ for $\mathrm{Cu}, 40.0-55.7 \mathrm{mg} / \mathrm{g}$ for $\mathrm{Mn}, \mathrm{ND}-102.5 \mathrm{mg} / \mathrm{g}$ for Fe, $\mathrm{ND}-305.0 \mathrm{mg} / \mathrm{g}$ for $\mathrm{Ni}, \mathrm{ND}-42.5 \mathrm{mg} / \mathrm{g}$ for $\mathrm{Zn}, \mathrm{ND}-23.8 \mathrm{mg} / \mathrm{g}$ for Ti, and $\mathrm{ND}-10.8 \mathrm{mg} / \mathrm{g}$ for Cr. The results showed that that these metals are at higher levels in Samples A, B, C and D compared to other studies in candies and chocolates in Nigeria. Correlation analysis among metals revealed positive correlations, which indicates similar sources of these metals. Also, evaluation of dietary intake of these products daily revealed that Samples A (except for $\mathrm{Cu}$ ), $\mathrm{B}$ and $\mathrm{C}$ are above the daily dietary recommended limit for all the studied metals in food. Thus a frequent intake of these contaminated products is likely to induce health effects arising largely from $\mathrm{Cu}, \mathrm{Mn}, \mathrm{Fe}$, Ni and Zn.
\end{abstract}

Keywords: heavy metals, candies, chocolates, risk, Nigeria

\section{Introduction}

Recently, there is an increasing concern about the quality of imported foods and food related products in several parts of the world (Maxwell \& Neumann, 2009) particularly from overseas. This is due to the large size of shipments, the many different routes of entry, the variety of foods imported, and the large numbers of potential contaminants make effective interdiction of contaminated foods difficult (CRS Report for Congress, 2008). Additionally, many products are brought into the country by travelers especially residents travelling back and forth regularly to the country. Among the common products imported are chocolates, candies, biscuits, bean paste, bean curd, teas and various nuts and spices (CRS Report for Congress, 2008).

Taking into consideration that products passed through different industrial processes and are packaged to provide a means of protecting, marketing or handling, and most of them are printed colour inks on the outer cover (Kim et al., 2008). Importantly, food products such as candies that are likely to be consumed frequently by small children are wrapped in colourful packages in order to induce them to purchase the products. Heavy metals, such as $\mathrm{Pb}, \mathrm{Cr}, \mathrm{Ti}, \mathrm{Zn}$ and $\mathrm{Cu}$ can migrate from the printed surface to the food contact surface through four mechanisms: blocking, rubbing, peeling and diffusion (Bradley et al., 2005). Contamination of imported food products with heavy metals may cause a serious risk for human health because of the consumption of even small amount of metals can lead to considerable concentrations in human body there leading to biotoxic effects. The biotoxic effects of heavy metals refer to the harmful effects of heavy metals to the body when consumed above the bio-recommended limits. Although individual metals exhibit specific signs of their toxicity, the following have been reported as general signs associated with cadmium, lead, arsenic, mercury, zinc, copper and aluminium poisoning: gastrointestinal (GI) disorders, diarrhoea, stomatitis, tremor, hemoglobinuria causing a rust-red colour to stool, ataxia, paralysis, vomiting and convulsion, depression, and pneumonia when volatile 
vapours and fumes are inhaled (McCluggage, 1991). The nature of effects could be toxic (acute, chronic or sub-chronic), neurotoxic, carcinogenic, mutagenic or teratogenic.

However, from previous studies, majority of them are carried out in developed countries and no literature of such studies in developing country like Nigeria where such "Junks" are constantly circulated in our markets are end-up consumed by families. Hence this study is necessitated to identify and characterized imported candies. This is because, the safety of our food products supply is a shared responsibility, from the fork of the food producing industry, regulatory authorities, scientist and consumers. As part of this responsibility, this study was conceived to assess the level of some heavy metals in candies sold in Nigeria market and the potential risks caused as a result of its consumption.

\section{Materials and Methods}

\subsection{Sampling}

The sampling was carried out in December 2009 based on information of NAFDAC Impoundment of Unregistered Imported Products in Kaduna (Thisday Newspaper, 21-09-2009). A total of 1 brand of chocolate and 3 brands candies (royal glucose biscuits - coded A; lollipops with pencils - coded B; Paravo chocolate cherry - coded C; and Martino milk candy - coded D) were collected from five major market each from a state in each geocgraphical zone of Nigeria: North-West (Bauchi), North-East (Kano), North-Central (Kogi), South-West (Lagos), South-East (Aba) and South-South (PortHarcourt). Before the choice of the sampling markets in each zone, a survey was carried out to ensure that these products are sold across the length and breadth of Nigeria. From each sample product, 12 samples were purchased randomly from five major markets from each geographical zone were composite to form a representative sample for the zone. Same batch of the same products were purchase directly from the vendors. Each representative was also assigned an identified code as mentioned above and securely stored at room temperature until it was send to the laboratory for $\mathrm{Cu}, \mathrm{Mn}, \mathrm{Fe}$, $\mathrm{Ni}, \mathrm{Zn}, \mathrm{Ti}$ analysis using XRF. The X-Ray Florescence Spectroscopy (XRF) analysis was conducted at the X-Ray Fluorescence Analytical Research Laboratory of Centre for Energy Research and Training of the Obafemi Awolowo University, Ife, Nigeria. The procedure used was reported by Funtua (1999), and Hassan and Umar (2004). $0.5 \mathrm{~g}$ of the pulverized samples each was homogenized with 3 drops of an organic binder (Polystyrene dissolved in toluene). This was pressed at 10 tons with a hydraulic press (SPECAC) to form a pellet of $19 \mathrm{~mm}$ diameter die. The pellets were introduced into the Energy Dispersive Spectrophotometer consist an annular $25 \mathrm{mci} \mathrm{Cd}-109$ isotope as the excitation source emitting Ag-K X-ray $(221 \mathrm{keV})$ and a Mo X-ray tube (50KV, $5 \mathrm{MA})$.

\section{Results}

The concentrations of heavy metals in different chocolate and candies (Sample A, B, C and D) are presented in Figures 1 - 4. The concentrations of heavy metals in Sample A ranged from 3.2 (Site 2) $-4.2 \mathrm{mg} / \mathrm{g}$ (Site 5) Cu, 54.0 (Sites 1, 2, and 5) - 54.8mg/g (Sites 4 and 6) Mn, 101.0 (Site 2) - 102.5mg/g (Site 3) Fe, 3.0 (Sites 2 and 5) - 3.5mg/g (Site 3) Ni, 2.5 (Sites 1, 2 and 3) - 26.0mg/g (Site 5) Zn, 23.0 (Sites 1 and 3) - 23.8mg/g (Sites 4 and 6) $\mathrm{Ti}$, no Cr was detected in across the sites for Sample C. For Sample B, the range of 3.7 (Site 2) $-4.2 \mathrm{mg} / \mathrm{g}$ (Sites 3 and 5) Cu, 40.5 (Site 3) - 41.3mg/g (Site 4) Mn, 37.0 (Sites 3 and 5) - 37.5mg/g (Sites 1, 4 and 6) Fe, 5.0 (Sites 1, 2 and 3) $-5.2 \mathrm{mg} / \mathrm{g}$ (Sites 4 and 6) Ni, 40.1 (Site 5) - 42.5mg/g (Sites 4 and 6), Ti and Cr were not detected in across the sites. Also, the metal concentration in Sample C ranged between 2.6 (Site 2) $-3.5 \mathrm{mg} / \mathrm{g}$ (Site 5) Cu, 54.0 (Sites 1 and 3) - 55.0mg/g (Site 6) Mn, 100.0 (Site 1) - 102.0mg/g (Site 2) Fe, 292.0 (Site 4) $305.0 \mathrm{mg} / \mathrm{g}$ (Site 5) Ni, 25.0 (Sites 2 and 4) - 26.7mg/g (Site 5) Zn, 13.0 (Site 4) - 14.7mg/g (Site 5) Ti, Cr was not detected in any of the sites. In Sample D, metal concentrations range between 3.2 (Site 2) $-4.2 \mathrm{mg} / \mathrm{g}$ (Site 6) $\mathrm{Cu}, 54.0$ (Sites 1, 4 and 5) - 55.7mg/g (Site 6) Mn, 13.6 (Site 3) - 15.5mg/g (Site 6) Ti, 10.0 (Site 1) - 11.0mg/g (Site 5) $\mathrm{Cr}$, and $\mathrm{Fe}$, Ni and $\mathrm{Zn}$ were not detected. Multivariate correlation analysis of heavy metals in samples as shown in Tables $1-4$ revealed positive correlation among $\mathrm{Mn} \mathrm{Vs} \mathrm{Cu}, \mathrm{Fe} \mathrm{Vs} \mathrm{Cu}$ and $\mathrm{Mn}, \mathrm{Ni} \mathrm{Vs} \mathrm{Mn}$ and $\mathrm{Fe}, \mathrm{Zn}$ $\mathrm{Vs} \mathrm{Cu}(\mathrm{p}<0.05)$ and $\mathrm{Mn}$, Ti Vs Cu, Mn and $\mathrm{Zn}$ for Sample A, Fe Vs Cu and Mn, Ni Vs Cu, Mn and Fe, and $\mathrm{Zn}$ Vs Fe for Sample B, Mn Vs Cu, Fe Vs Mn, Ni Vs Cu, Mn and Fe, Zn Vs Cu, Mn and Ni, and Ti Vs Cu, Mn, Fe and $\mathrm{Ni}(\mathrm{p}<0.01)$ for Sample C, and Mn Vs Cu, Ti Vs Cu and Mn, and Cr Vs Cu for Sample D. However, others are either negative or no correlation value. The positive correlations indicates similar source of these metals in the sample, with contamination of raw materials such as sugar, cocoa, milk and flour, and wrappers of these products likely to be the sources of these metals. 
Table 1. Correlation analysis of among metals in Sample A

\begin{tabular}{cccccccc}
\hline Parameter & $\mathbf{C u}$ & $\mathbf{M n}$ & $\mathbf{F e}$ & $\mathbf{N i}$ & $\mathbf{Z n}$ & $\mathbf{T i}$ & $\mathbf{C r}$ \\
\hline $\mathbf{C u}$ & 1.000 & & & & & \\
$\mathbf{M n}$ & 0.458 & 1.000 & & & & \\
$\mathbf{F e}$ & 0.399 & 0.710 & 1.000 & & & \\
$\mathbf{N i}$ & -0.287 & 0.255 & 0.349 & 1.000 & & \\
$\mathbf{Z n}$ & $0.877^{*}$ & 0.123 & -0.089 & -0.524 & 1.000 & & \\
$\mathbf{T i}$ & 0.456 & 0.513 & -0.171 & -0.384 & 0.587 & 1.000 &. $\mathrm{a}$ \\
$\mathbf{C r}$ &. $\mathrm{a}$ &. $\mathrm{a}$ &. $\mathrm{a}$ &.$^{\mathrm{a}}$ &. &. \\
\hline
\end{tabular}

*: Correlation is significant at the 0.05 level (2-tailed).

${ }^{a}$ : Cannot be computed because at least one of the variables is constant.

Table 2. Correlation analysis of among metals in Sample B

\begin{tabular}{|c|c|c|c|c|c|c|c|}
\hline Parameter & $\mathbf{C u}$ & Mn & $\mathbf{F e}$ & $\mathbf{N i}$ & $\mathbf{Z n}$ & $\mathbf{T i}$ & $\mathrm{Cr}$ \\
\hline $\mathrm{Cu}$ & 1.000 & & & & & & \\
\hline Mn & -0.164 & 1.000 & & & & & \\
\hline $\mathbf{F e}$ & 0.051 & 0.121 & 1.000 & & & & \\
\hline $\mathbf{N i}$ & 0.129 & 0.660 & 0.478 & 1.000 & & & \\
\hline Zn & -0.494 & -0.307 & 0.614 & 0.135 & 1.000 & & \\
\hline Ti &.$^{\mathrm{a}}$ &.$^{\mathrm{a}}$ &.$^{\mathrm{a}}$ &.$^{\mathrm{a}}$ &.$^{\mathrm{a}}$ &.$^{\mathrm{a}}$ & \\
\hline $\mathrm{Cr}$ & ${ }^{\mathrm{a}}$ &.$^{\mathrm{a}}$ &.$^{\mathrm{a}}$ &.$^{\mathrm{a}}$ &.$^{\mathrm{a}}$ &.${ }^{\mathrm{a}}$ &.${ }^{\mathrm{a}}$ \\
\hline
\end{tabular}

${ }^{a}$ : Cannot be computed because at least one of the variables is constant.

Table 3. Correlation analysis of among metals in Sample C

\begin{tabular}{cccccccc}
\hline Parameter & $\mathbf{C u}$ & $\mathbf{M n}$ & $\mathbf{F e}$ & $\mathbf{N i}$ & $\mathbf{Z n}$ & $\mathbf{T i}$ & $\mathbf{C r}$ \\
\hline $\mathbf{C u}$ & 1.000 & & & & & & \\
$\mathbf{M n}$ & 0.332 & 1.000 & & & & \\
$\mathbf{F e}$ & -0.087 & 0.157 & 1.000 & & & \\
$\mathbf{N i}$ & 0.378 & 0.318 & 0.421 & 1.000 & & & \\
$\mathbf{Z n}$ & 0.746 & 0.314 & -0.303 & 0.662 & 1.000 & & \\
$\mathbf{T i}$ & 0.259 & 0.486 & 0.432 & $0.938^{* *}$ & 0.538 & 1.000 &. \\
$\mathbf{C r}$ &. $\mathrm{a}$ &. $\mathrm{a}$ &. &.$^{\mathrm{a}}$ &. &.$^{\mathrm{a}}$ &.$^{\mathrm{a}}$ \\
\hline
\end{tabular}

${ }^{\mathrm{a}}$ : Cannot be computed because at least one of the variables is constant.

**: Correlation is significant at the 0.01 level (2-tailed). 
Table 4. Correlation analysis of among metals in Sample D

\begin{tabular}{|c|c|c|c|c|c|c|c|}
\hline Parameter & $\mathbf{C u}$ & Mn & $\mathrm{Fe}$ & $\mathbf{N i}$ & $\mathbf{Z n}$ & $\mathbf{T i}$ & $\mathrm{Cr}$ \\
\hline $\mathbf{C u}$ & 1.000 & & & & & & \\
\hline Mn & 0.491 & 1.000 & & & & & \\
\hline $\mathrm{Fe}$ &.$^{\mathrm{a}}$ & a &.${ }^{\mathrm{a}}$ & & & & \\
\hline $\mathbf{N i}$ &.${ }^{\mathrm{a}}$ &. a &.${ }^{\mathrm{a}}$ &.${ }^{\mathrm{a}}$ & & & \\
\hline $\mathbf{Z n}$ &.${ }^{\mathrm{a}}$ &.${ }^{\mathrm{a}}$ &.$^{\mathrm{a}}$ &.${ }^{\mathrm{a}}$ &.${ }^{\mathrm{a}}$ & & \\
\hline $\mathbf{T i}$ & 0.684 & 0.388 &.$^{\mathrm{a}}$ &.${ }^{\mathrm{a}}$ &.${ }^{\mathrm{a}}$ & 1.000 & \\
\hline $\mathrm{Cr}$ & 0.048 & -0.124 &.${ }^{\mathrm{a}}$ &.${ }^{\mathrm{a}}$ &. $\mathrm{a}$ & 0.544 & 1.000 \\
\hline
\end{tabular}

${ }^{\mathrm{a}}$ : Cannot be computed because at least one of the variables is constant.

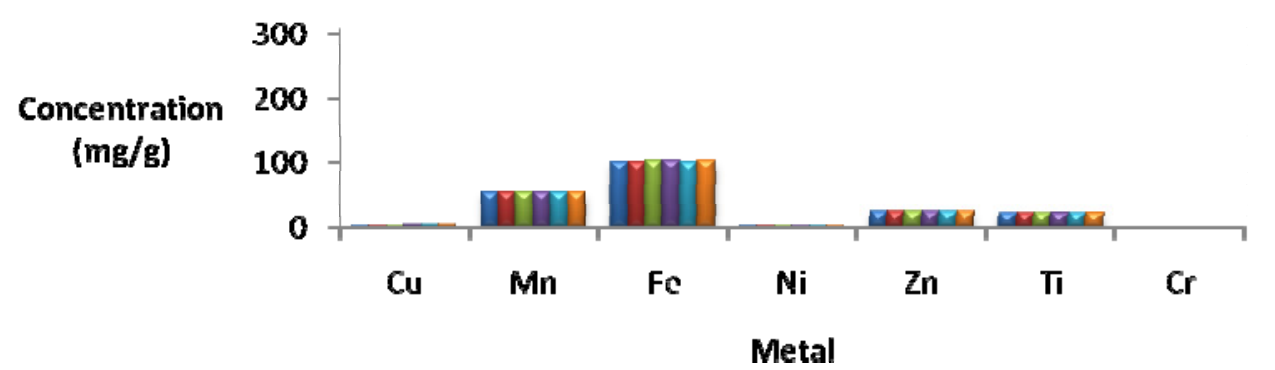

Figure 1. Concentration of heavy metals in Sample A

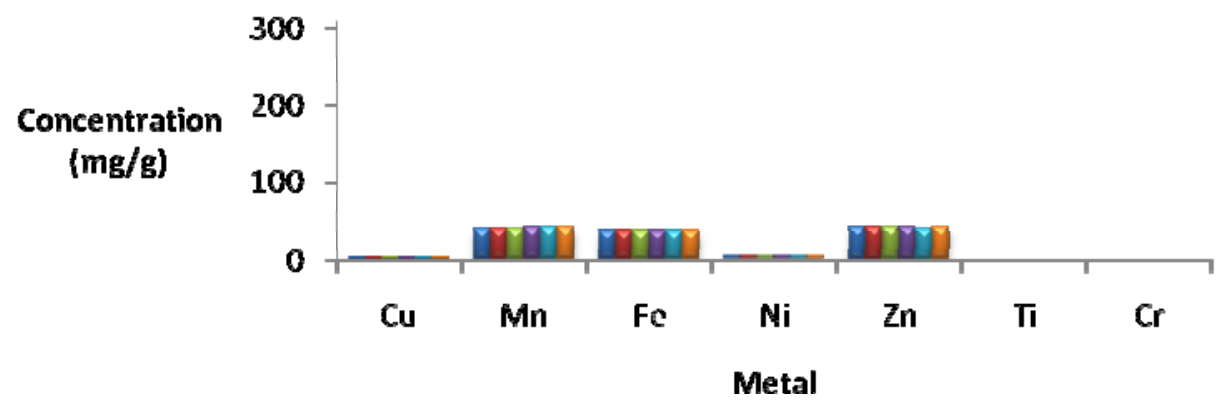

Figure 2. Concentration of heavy metals in Sample B

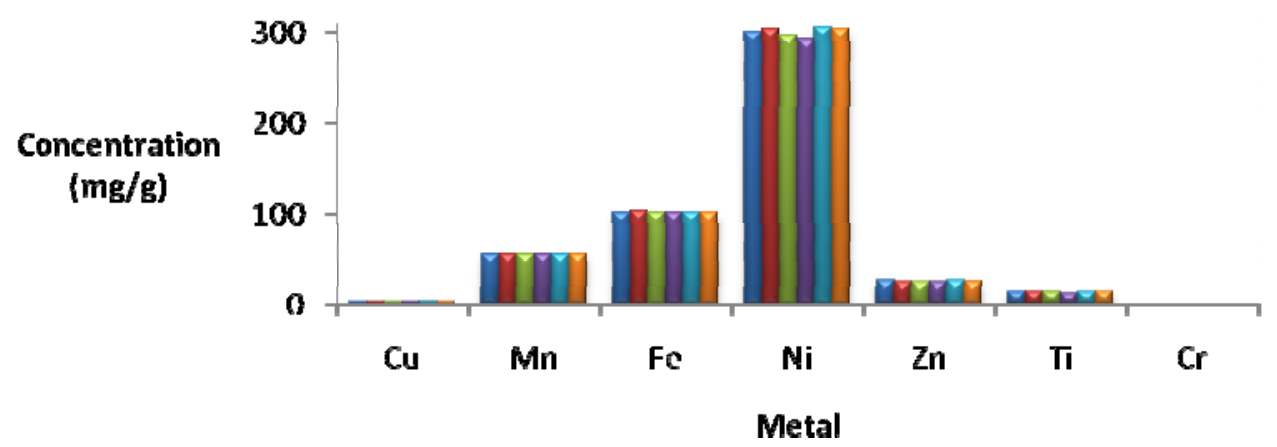

Figure 3. Concentration of heavy metals in Sample C
Dite 1

$\square$ site 2

$\square$ site 3

asite4

asites

प5ite 6 asite 1

asite 2

asite 3

0 site 4

9 sites

$95 i t e 6$ asite 1

asite 2

$95 i t e 3$

asite 4

asite 5

घsite 6 


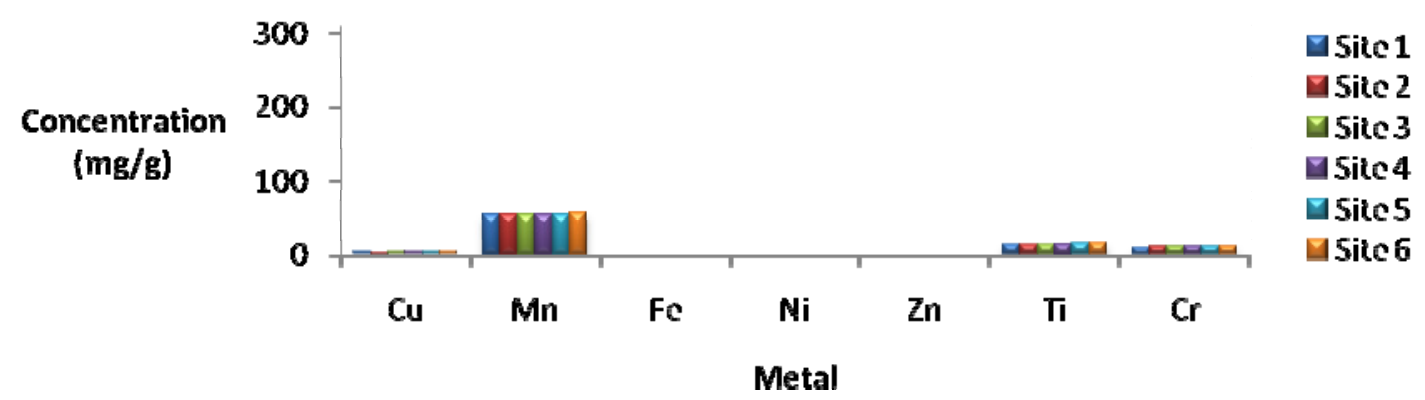

Figure 4. Concentration of heavy metals in Sample D

\section{Discussion}

Heavy metal composition of food, candies and chocolates is of interest because of their essential or toxic nature. For example, $\mathrm{Fe}, \mathrm{Zn}, \mathrm{Cu}, \mathrm{Cr}, \mathrm{Co}, \mathrm{Ni}$ and $\mathrm{Mn}$ are essential while $\mathrm{Pb}, \mathrm{Cd}$ and $\mathrm{Hg}$ are toxic (Onianwa et al., 1999). Though, there are no well defined limits for these metals in chocolates and candies, rather daily intake limits of these metals in food are given by WHO, which will be discussed in a later section. Hence, comparison of the results obtained in this study with other reported studies in literature on metals in candies and chocolates will be difficult, since limited studies are available, and those available are not easily accessible (Iwegbue, 2011). Hence in this study, results obtained are compared to recommended standard limits for these metals in food.

However, from the results, the average highest level of $\mathrm{Cu}$ was recorded in Sample B (lollipop) with constituents majorly sugar and flour. Intake of $\mathrm{Cu}$ in the samples compared to $0.0733 \mathrm{mg} / \mathrm{g}$ limits reported in vegetable could be confirmed high. This could be related to high amount of copper in the raw material and likely processing of these materials. There is greater risk of health effects from deficiency of copper intake than from excess copper intake. Acute toxicity due to ingestion of copper is infrequent in humans. However, when it occurs it is usually a consequence of the migration of copper into chocolates and candies or from accidental or deliberate ingestion of high quantities of copper salts. Symptoms include vomiting, lethargy, acute hemolytic anaemia, renal and liver damage, neurotoxicity, increased blood pressure and respiratory rates. In some cases, coma and death followed (Environmental Health Criteria for Copper, 1996). Chronic copper poisoning has not been described in general population (Naseth \& Norseth, 1986). Results of this study showed that chocolates and candies are significant sources of childhood copper exposure in Nigeria. Thus repeated consumption of these products with high levels of $\mathrm{Cu}$ may pose a risk in reduction of total homocysteine and folate which are essential to body metabolism (Tamura \& Turnland, 2004).

Also, from the results, high levels of Mn was recorded in Sample D, and samples have values above the 0.00004 $-0.0126 \mathrm{mg} / \mathrm{g}$ reported for chocolates and candies in southern Nigeria (Iwegbue, 2011). This implies that impoundment of this products could be related to this reason. Metals are present in food either naturally or as a result of human activities such as agricultural practices, industrial emissions, car exhausts, or contamination during manufacturing. For chocolates and candies, contamination may also occur due to raw materials and water used. Manganese is present in most foodstuffs. The main contributors of manganese to the diet are cereals (10-30 $\mathrm{mg} / \mathrm{kg}$ ) as well as vegetables and fruits $(0.5-5 \mathrm{mg} / \mathrm{kg}$ ) (Beliles, 1994; Codex, 1995). Nuts may have a high content of manganese. In some countries, manganese has replaced organic lead as an additive in petrol. This might result in increasing concentrations of manganese in the environment and in foodstuffs in the future. Manganese is an essential trace element that plays a role in bone mineralization, protein and energy metabolism, metabolic regulation, cellular protection from damaging free radical species, and the formation of glycosaminoglycans (ATSDR, 1997). Although manganese is an essential nutrient, exposure to high levels via inhalation or ingestion may cause some adverse health effects (ATSDR, 1997). Excess manganese affects the central nervous system and the neurological effects have been observed in case of occupational exposure. No problems are reported in connection with intake of manganese with foodstuff as manganese is considered one of the least toxic metals. Consistent with its role as an essential element, manganese and its inorganic compounds have a relatively low order of acute toxicity (Beliles, 1994). However, the absorption is increased in individuals with iron deficiency. In humans, the degree of manganese absorption from the gastrointestinal system is generally low, to the order of $3 \%$ (Beliles, 1994).

With exception of Samples A, B and D, Fe is the most abundant among all the studied metals. Fe ranged between 
$\mathrm{ND}-102.5 \mathrm{mg} / \mathrm{g}$, higher than $0.0017-0.0123 \mathrm{mg} / \mathrm{g}$ reported by Iwegbue (2011). High levels in this study could be attributed to the fact that $\mathrm{Fe}$ is the fourth most abundant element (5\%) in the earth's crust (Beliles, 1994) where soils are made and the raw materials for these products are grown. Iron is present in most foods and beverages. In general, liver, kidney, beef, ham, egg yolk, and soybeans have iron concentrations to the order of $30-150 \mathrm{mg} / \mathrm{kg}$ (Elinder, 1986). In several countries the cereal most commonly eaten, e.g., wheat flour, is fortified with iron in order to provide the necessary amount of iron in the diet (Nordic Council of Ministers, 1995). Food contamination by iron may originate from food processing equipment, containers and other utensils used for foodstuff. The iron leaching to canned foodstuffs depends on storage time of the food product. Rare cases of release of very high quantities of iron from food contact materials such as iron kitchen utensils have been observed (Codex, 1995). Iron is an essential trace metal (JECFA, 1983). Iron is mainly a deficiency problem and not a toxicological problem. Iron deficiency is generally acknowledged to be the most common, single nutritional deficiency in both developing and developed countries (Nordic Council of Ministers, 1995). Certain iron salts, mainly ferrous sulphate and ferrous succinate, are frequently used for the treatment and prevention of iron deficiency in humans (Beliles, 1994). Under normal conditions, about $5-15 \%$ of the iron is absorbed (Elinder, 1986). Ingestion of soluble iron salts by children in doses exceeding $0.5 \mathrm{~g}$ of iron can give rise to severe lesions in the gastrointestinal tract, followed by metabolic acidosis, shock and toxic hepatitis (Elinder, 1986).

Among the studied samples, $\mathrm{Ni}$ is exceptionally high in Sample C compared to others. This value is much higher than trace amount $(0.0014-0.0079 \mathrm{mg} / \mathrm{g})$ obtained in chocolates and candies sold in southern Nigeria markets (Iwegbue, 2011). Nickel is found in small quantities in many foodstuffs $(0.001-0.01 \mathrm{mg} / \mathrm{kg}$ ) and in higher concentrations in foodstuffs such as grains, nuts, cocoa products and seeds (up to $0.8 \mathrm{mg} / \mathrm{kg}$ ) (National Food Agency of Denmark, 1995). In the diet it is found as complex bound $\mathrm{Ni}^{2+}$ ions (Codex, 1995). The absorption and retention of nickel in the gastrointestinal tract is influenced by fasting and food intake. Food intake and gastric emptying are of substantial significance for the bioavailability of nickel from aqueous solutions. The absorption of free nickel ions released in the gastrointestinal tract may be 40 times higher than that of complex-bound nickel from foodstuff (Sunderman et al., 1989). The absorption of nickel from drinking water is increased by fasting (Nielsen et al., 1999). Inorganic nickel compounds are absorbed to $10 \%$ or less from the gastrointestinal tract (Norseth, 1986). Nickel intake via foodstuff does not cause hazards for the majority of consumers (Codex, 1995). A subgroup of the population (app. 10\%, mainly women) have contact allergy to nickel. Nickel allergy is only caused by absorption of nickel through the skin (Codex, 1995). The highest value of $\mathrm{Zn}$ in chocolates and candies $(42.5 \mathrm{mg} / \mathrm{g})$ in this study is lower than reported value of $0.0006-0.008 \mathrm{mg} / \mathrm{g}$ in chocolates and candies sold in southern Nigeria markets (Iwegbue, 2011). Zinc is an essential trace metal (Elinder, 1986). Zinc is the $25^{\text {th }}$ most abundant element and is widely found in nature (Beliles, 1994). Zinc appears in the form of zinc ions or zinc salts (Codex, 1995). Zinc is one of the most ubiquitous of the essential trace metals (Florence \& Batley, 1980). The absorption of ingested zinc is highly variable (10-90\%) (Elinder, 1986). Zinc is an essential element necessary for the function of a large number of metalloenzymes (ATSDR, 1992; Beliles, 1994). Zinc acts to diminish the toxicity of cadmium and copper (Florence \& Batley, 1980). Zinc may be a modifier of the carcinogenic response; zinc deficiency or excessively high levels of zinc may enhance susceptibility to carcinogenesis (Beliles, 1994).

With exception of Sample B, Ti is present in all the samples analysed. No related reports of Ti in chocolates and candies. However, $\mathrm{Ti}$ is the ninth most common element in the earth's crust and occurs in a number of minerals (Beliles, 1994). There is no evidence indicating that titanium is an essential element for man (Nordman \& Berlin, 1986). Titanium is used in the form of the dioxide as a colour additive in confectionary, dairy products and soft drinks, etc. (Directive 95/2/EC). Also, titanium is used as additives to edible inks, toothpaste, and pharmaceuticals (Whitehead, 1991). Titanium compounds are generally considered to be poorly absorbed upon ingestion (Nordman \& Berlin, 1986). Studies on titanium alloys used in implants and titanium compounds used in cosmetics and pharmaceuticals do not indicate any local effects on tissues (Nordman \& Berlin, 1986). A distinct toxicological dichotomy exists between $\mathrm{TiO}$, the insoluble, unreactive non-metabolized form devoid of toxicity, and the soluble, inorganic salts that metabolize normally with absorption, distribution, and excretion (Beliles, 1994). However, little information exists on how titanium acts as a toxic agent, and what does exist is of little or no value in understanding the toxic actions of titanium (Beliles, 1994).

Similar to other metals, concentrations of $\mathrm{Cr}$ in the samples are higher than $0.00004-0.003 \mathrm{mg} / \mathrm{g}$ reported by Iwegbue (2011). The main sources of chromium are cereals, meat, vegetables and unrefined sugar, while fish, vegetable oil and fruits contain smaller amounts (Codex, 1995). Most foodstuffs contain less than $0.1 \mathrm{mg}$ chromium per $\mathrm{kg}$ (Nordic Council of Ministers, 1995). Chromium is present in the diet mainly as $\mathrm{Cr}$ (III) (Codex, 1995). As with all metals, food contamination may be caused by atmospheric fall-out (Codex, 1995). Chromium 
is found in the environment mainly in the trivalent form. Hexavalent chromium, or chromate, may also be found in very small amounts, arising usually from anthropogenic sources (Beliles, 1994). Cr (III) has the ability to form strong, inert complexes with a wide range of naturally occurring organic and inorganic ligands (Florence and Batley, 1980). In most soils and bedrocks, chromium is immobilised in the trivalent state (Florence and Batley, 1980). Chromium is an essential element to man. Chromium is found at low levels in most biological materials. Cr (III), the most stable oxidation state in biological materials, is an essential element for normal glucose metabolism, while $\mathrm{Cr}(\mathrm{VI})$ is highly toxic (Beliles, 1994; Costa, 1997; Nordic Council of Ministers, 1995). $\mathrm{Cr}$ (III) has a low toxicity due to low absorption (about 0.5\%) (Nordic Council of Ministers, 1995). Toxic aspects of chromium are related to $\mathrm{Cr}(\mathrm{VI})$, due to its high absorption, easy penetration of the cell membranes and its genotoxicity and oxidising properties (Codex, 1995).

\subsection{Estimated Daily Intake of Metals}

To appraise the health risk associated with heavy metal contamination of the studied products, estimated daily intake of metal (EDIM) was calculated as shown below according to Zhuang et al. (2009).

$$
D I M=\frac{\mathrm{C}_{\text {metal }} \times \mathrm{C}_{\text {food }}}{\mathrm{B}_{\mathrm{w}}}
$$

Where,

$\mathrm{C}_{\text {metal }}(\mathrm{mg} / \mathrm{g})$ is the concentration of heavy metals in the samples;

$\mathrm{W}_{\text {food }}$ represents the daily average weight of the sample consumed (Assumed $20 \mathrm{~g}$ of each sample is taken by an individual);

$\mathrm{B}_{\mathrm{w}}$ is the body weight assuming that Samples are consumed by children between the ages of 1-5 years with average body weight of $20 \mathrm{~kg}$.

The estimated daily intake of metals (EDIM) value for the products studied is shown in Table 5. The trends of EDIMs for the heavy metals in the samples were in the order of:

Sample A: $\mathrm{Fe}>\mathrm{Zn}>\mathrm{Ti}>\mathrm{Cr}>\mathrm{Mn}>\mathrm{Cu}=\mathrm{Ni}$

Sample B: $\mathrm{Zn}>\mathrm{Mn}>\mathrm{Fe}>\mathrm{Ni}>\mathrm{Cu}>\mathrm{Ti}=\mathrm{Cr}$

Sample C: $\mathrm{Ni}>\mathrm{Fe}>\mathrm{Mn}>\mathrm{Zn}>\mathrm{Ti}>\mathrm{Cu}>\mathrm{Cr}$

Sample D: $\mathrm{Mn}>\mathrm{Ti}>\mathrm{Cr}>\mathrm{Cu}>\mathrm{Fe}=\mathrm{Ni}=\mathrm{Zn}$.

Table 5. Estimated Daily Intake (mg/day) in study samples

\begin{tabular}{cccccccc}
\hline Sample & & \multicolumn{7}{c}{ Metal } \\
\hline & $\mathbf{C u}$ & $\mathbf{M n}$ & $\mathbf{F e}$ & $\mathbf{N i}$ & $\mathbf{Z n}$ & $\mathbf{T i}$ & $\mathbf{C r}$ \\
\hline $\mathbf{A}$ & 1.3 & 5.6 & 18.9 & 1.3 & 10.7 & 7.5 & 6.1 \\
$\mathbf{B}$ & 4.0 & 41.0 & 37.3 & 5.1 & 41.9 & 0.0 & 0.0 \\
$\mathbf{C}$ & 3.0 & 54.4 & 101.0 & 299.3 & 25.7 & 14.1 & 0.0 \\
$\mathbf{D}$ & 3.6 & 54.5 & 0.0 & 0.0 & 0.0 & 14.4 & 10.5 \\
UK Limit & 1.4 & 4.5 & 15.0 & 0.1 & 11.0 & & 0.1 \\
\hline
\end{tabular}

Also, the results revealed $\mathrm{Ni}, \mathrm{Fe}, \mathrm{Zn}$ and $\mathrm{Mn}$ have the highest intake among the samples. It should be noted that the EDIM estimation is a risk assessment designed to avoid underestimation of the risk. Thus, it incorporated several assumptions such as ingested quantities of metal ions correspond to the quantities that are absorbed (USEPA, 1989). Hence, the DIMs values of $\mathrm{Cu}$ as revealed in the results showed that Sample A and B are below than $1.4 \mathrm{mg}$ /day recommended limit for $\mathrm{Cu}$ in UK (Ysart et al., 2000). However, the EDIM for other samples were found to be 2 folds higher than the stipulated limits, with the biggest contribution to the intake of $\mathrm{Cu}$ from Sample B.

The contribution of overall EDIM values resulting from levels of Mn as shown in the results showed that all the samples have their EDIM values above the $4.5 \mathrm{mg}$ /day threshold limit recommended (Ysart et al., 2000). Similarly, for Fe and $\mathrm{Zn}$, all the samples except Sample D is above the 15.0 and $11.0 \mathrm{mg} /$ day recommended for 
Fe and $\mathrm{Zn}$ daily dietary intake (Ysart et al., 2000). Also, for Ni, all the samples except Sample D are above the $0.1 \mathrm{mg}$ /day recommended limit while for $\mathrm{Cr}$, Sample A and D are above $0.1 \mathrm{mg} /$ day the recommended limits.

Generally, the results revealed that Sample A (except for $\mathrm{Cu}$ ), B and $\mathrm{C}$ are above the daily dietary recommended limit for all the studied metals in the samples. Thus a frequent intake of these contaminated products is likely to induce health effects arising largely from $\mathrm{Cu}, \mathrm{Mn}, \mathrm{Fe}, \mathrm{Ni}$ and $\mathrm{Zn}$.

\section{Conclusion}

In overall, our study showed that not all the studied metals were found in the samples; non detection of $\mathrm{Ti}$ and $\mathrm{Cr}$ in Samples A and B, Cr in Sample A and C, and Fe, Ni and Zn in Sample D. However, all the metals found in a sample are generally higher than reported values for chocolates and candies. The reasons for the high levels of the metals in the samples could arise unsafe storage conditions or at any point in the production chain i.e from the raw materials, processing, packaging, transportation, storage or marketing.

Also, evaluation of dietary intake of these products daily revealed that Sample A (except for $\mathrm{Cu}$ ), B and C are above the daily dietary recommended limit for all the studied metals in food. Thus a frequent intake of these contaminated products is likely to induce health effects arising largely from $\mathrm{Cu}, \mathrm{Mn}, \mathrm{Fe}, \mathrm{Ni}$ and $\mathrm{Zn}$. The choice of these products may vary considerably among the populations and the choice of these kinds of products consumed is dependent on culture. Since candies and chocolates are favorites food items of children, often given to them by their parents, friends and relatives as a sign of love and affection. Hence children are the group most vulnerable to contamination through eating of chocolates and candies.

These data provide convincing evidence that these imported products from China contained unacceptable levels of heavy metals potentially serious consequences for children and adults who consume the products. The results also agree with the argument of NAFDAC and SON of the questionable quality of products imported from China (This Day, 2007) which poses a potentially significant public health threat.

\section{References}

ATSDR. (1997). Toxicological profile for aluminium. Draft for public comment. U. S. Department of Health and Human Services. Public Health Service. Agency for Toxic Substances and Disease Registry.

Beliles, R. P. (1994). The metals. In: Patty's Industrial Hygiene and Toxicology, Fourth edition, Volume 2, Part C. Edited by Clayton, G.D., and Clayton, F.E. John Wiley \& Sons, Inc.

Bradley, E. L., Castle, L., Dines, T. J., Fitzgerald, A. G., Gonzalez, T. P., \& Jickells, S. M. (2005). Test method for measuring non-visible set-off from inks and lacquers on the food contact surface of printed packaging $\begin{array}{llll}\text { materials. } \quad \text { Food Additives and } & \text { Contaminants, } 2(5), 502 .\end{array}$ http://dx.doi.org/10.1080/02652030500129253

Codex Alimentarius Commission. (1995). Doc. no. CX/FAC 96/17. Joint FAO/WHO food standards programme. Codex general standard for contaminants and toxins in foods.

CRS Report for Congress. (2008). Food and agricultural crops from China by Geoffrey S. B. Specialist in Agricultural Policy Resources, Science and Industry Division, US. Directive 93/43/EEC: Council directive on the hygiene of foodstuffs, L 175, p. 1-11.

Elinder, C. G. (1986). Zinc. In: Friberg, L., Nordberg, G.F., Vouk, V.B. Handbook on the toxicology of metals. Second edition. Elsevier, Amsterdam, New York, Oxford.

Environmental Health Criteria for Copper. (1996). PCS/EHC 96.28 unedited, p. 9.

Florence, T. M., \& Batley, G. E. (1980). Chemical speciation in natural waters. CRC Critical Reviews in Analytical chemistry, p. 219-296. http://dx.doi.org/10.1080/10408348008085597

Funtua, I. I. (1999). Analysis of Ta and Nb Ores by Energy Dispersive X-Ray Fluorescence Spectroscopy. J. Trace and Microprobe Techniques, 17(2), 195 - 197.

Hassan, L. G., \& Umar. K. J. (2004). Effect of Drying Methods on Nutrients of Icrateva religiosa Leaves. Nigeria Journal of Renewable Energy, 3(1), 14-17.

Iwegbue, C. M. A. (2011). Concentration of selected metals in candies and chocolates consumed in southern Nigeria. Food additives and Contaminants, Part B 4(1), 22-27.

JECFA. (1983). Evaluation of certain food additives and contaminants. Thirty-third report of the Joint FAO/WHO Expert Committee on Food Additives. World Health Organization, Technical Report Series, 776. 
Kim, K. C., Park, Y. B., Lee, M. J., Kim, J. B., Huh, J. W., Kim, D. H., Lee, J. B., \& Kim, J, C. (2008). Levels of heavy metals in candy packages and candies likely to be consumed by small children. Food Research International, 41, 411-418. http://dx.doi.org/10.1016/j.foodres.2008.01.004

Maxwell, E. M. S., \& Neumann, C. (2009). Food sources of lead may exacerbate occupational exposure to lead: recommendations for occupational investigations. Journal of SH and E Research, 6(1), 1-16.

McCluggage, D. (1991). Heavy Metal Poisoning, NCS Magazine, Published by The Bird Hospital, CO, USA.

Naseth, J., \& Norseth, T. (1986). Copper. In: Friberg, L., Nordberg, G.F., Vouk, V.B. Handbook on the toxicology of metals. Second edition. Elsevier, Amsterdam, New York, Oxford.

National Food Agency of Denmark. (1995). Food monitoring, 1988-1992. $\mathrm{http} / / /$ www.unece.org/stats/documents/ce

Nielsen, G. D., Søderberg, U., Jørgensen, P. J., Tempelton, D. M., Rasmussen, S. N., Andersen, K. E., Grandjean, P. (1999). Absorption and retention of nickel from drinking water in relation to food intake and nickel sensitivity. Toxicology and Applied Pharmacology, 154(1), 67-75. http://dx.doi.org/10.1006/taap.1998.8577

Nordic Council of Ministers. (1995). Risk evaluation of essential trace elements - essential versus toxic levels of intake. Report of a Nordic project group. Ed.: Oskarsson, A. Nordic Council of Ministers, Copenhagen, Denmark.

Nordman H., \& Berlin M. (1986). Titanium. In: Friberg L, Nordberg GF, Vouk V, et al., eds. Handbook of the toxicology of metals. 2nd ed. Amsterdam: Elsevier Science Publishers B. V., 595-609.

Norseth, T. (1986). Nickel. In: Friberg, L., Nordberg, G.F., Vouk, V.B. Handbook on the toxicology of metals. Second edition. Elsevier, Amsterdam, New York, Oxford.

Onianwa, P. C., Adetola, I. G., Iwegbue, C. M. A., Ojo, M. F., \& Tella, O. O. (1999). Trace heavy metals composition of some Nigerian beverages and food drinks. Food Chemistry, 66, 275-279. http://dx.doi.org/10.1016/S0308-8146(98)00257-X

Sunderman, F. W. Jr, Hopfer, S. M., Sweeney, K. R., Marcus, A. H., Most, B. M., \& Creason, J. (1989). Nickel absorption and kinetics in human volunteers. Pro. Soc. Exp. Biol. Med., 191, 5-11.

Tamura, T., \& Turnlund, J. R. (2004). Effect of long-term, high copper intake on the concentrations of plasma homocysteine and B-vitamins in young men. Nutrition, 20(9), 757-759. http://dx.doi.org/10.1016/j.nut.2004.05.011

USEPA. (1989). Risk Assessment Guidance for Superfund: Human Health Evaluation Manual (Part A). Vol. I., USEPA, Washington.

Whitehead, J. (1991). Titanium. In.: Metals and their compounds in the environment. Occurrence, analysis and biological relevance. Ed.: Merian, E. VCH.

Ysart, G., Miller, P., Croasdale, M., Crews, H., Robb, P., Baxter, M., Largy, C., \& Harrison, N. (2000). UK total diet study exposure to aluminium, arsenic, cadmium, chromium, copper, lead, mercury, nickel, selenium, tin and zinc. Food Addit. Contam., 17, 775-786. http://dx.doi.org/10.1080/026520300415327

Zhuang, P., McBride, M. B., Xia, H., Li, N., \& Li, Z. (2009). Health risk from heavy metals via consumption of food crops in the vicinity of Dabaoshan mine, South China. Science of The Total Environment, 407, 1551-1561. http://dx.doi.org/10.1016/j.scitotenv.2008.10.061 